\title{
Cumhuriyetin IIlk Yıllarında Milli Eğitim Politikalarında Bir Araç Olarak Sinemanın Kullanılması: 1925 Şakir Seden Raporu
}

\author{
The Use of the Cinema as a Tool in National Education Policies in the Early Years of the Republic: \\ 1925 Şakir Seden Report
}

Murat Yıldı* (D)

Department of Political Science and Public Administration, Aksaray University, Aksaray, Turkey

\begin{abstract}
Received: 19.02 .2021
Accepted: 07.04 .2021

This article was checked by intihal.net

\section{Öz}

Sinemanın icat edilmesiyle Osmanlı sınırlarına girmesi arasındaki süre, çok uzun olmamıştır. İlk etapta yabancılar ve gayrimüslimler tarafından sürdürülen ve bir eğlence sektörü haline gelen sinemanın, halk üzerinde etkileyici bir propaganda aracı ve eğitici bir materyal olduğunun fark edilmeye başlanması, siyasi otoritelerin sinemaya olan bakış açılarının değişmesine de yol açmıştır. Sinemanın halk üzerindeki etkileyici yönü, dönemin aydınları tarafından da anlaşılmış, halkın ve öğrencilerin eğitimi konusunda sinemanın etkili bir biçimde kullanılabileceği fikrini doğurmuştur. Bu çalışmanın konusu, cumhuriyetin ilk yıllarında Maarif Vekâletinin izlediği politikalarda sinemanın yardımcı bir unsur olarak kullanılması amacıyla Şakir Seden'e hazırlattığı raporu konu edinmiştir. Şakir Seden, Maarif Vekâletinin direktifi ile sinemanın halkın ve öğrencilerin eğitiminde etkin bir araç olarak kullanılması konusunda bir rapor hazırlayarak vekâlete sunmuştur. Raporda, dönemin sinema sektörü, Türkiye'deki sinemanın mevcut durumu, getirtilmesi düşünülen sinema filmlerinin konuları ve Maarif Vekâletinin konuya ilişkin beklentilerine ilişkin bilgiler yer almıştır. Bu çalışmanın amacı, cumhuriyetin erken yıllarında devlet politikalarında ve bilhassa eğitim politikalarında sinemanın, halkın ve öğrencilerin eğitiminde kullanılması girişimi üzerinden dönemin siyasi otoritelerinin sinemaya bakış açısını ortaya koyarak Türk sinema tarihine, eğitim politikalarına ve Türk modernleşmesine dair bilgiler ortaya koyulmasıdır. Böylelikle sinema tarihi çalışan araştırmacıların yanı sıra disiplinler arası çalışan araştırmacılar başta olmak üzere, cumhuriyet dönemi eğitim-kültür politikaları, siyasi tarih ve devlet politikaları alanında çalışan araştırmacıların da istifade edebileceği bir çalışma ortaya konulması amaçlanmıştır.
\end{abstract}

Anahtar Kelimeler: Şakir Seden, Cumhuriyet Dönemi, Sinema Tarihi, Eğitim Politikaları

\section{Abstract}

The time between the invention of cinema and its entry into the Ottoman borders was not very long. The realization that cinema, which was carried out by foreigners and non-Muslims in the first place and became an entertainment sector, was an impressive propaganda tool and an educational material on the public, led to a change in the perspective of political authorities towards it. The impressive aspect of cinema on the public was also understood by the intellectuals of the period and led to the idea that cinema could be used effectively for the education of the public and students. The subject of this study is the report prepared by Şakir Seden in order to use cinema as an auxiliary element in the policies followed by the Ministry of Education in the first years of the republic. Şakir Seden prepared the report on the use of cinema as an effective tool in the education of the public and students with the directive of the Ministry of Education and submitted it to the proxy. The report included information about the cinema industry of the period, the current situation of cinema in Turkey, information regarding the issues and expectations related to matters to be considered by the Ministry of Education of imported films. The aim of this study is to reveal information about Turkish cinema history, educational policies and Turkish modernization by revealing the perspective of the political authorities of the period through the attempt to use of cinema in the education of the public and students in the state policies and especially in education policies in the early years of the republic. In this way, it is aimed to present a study that can be used by researchers working in the fields of education and culture policies of the republican period, political history and state policies, in addition to researchers working in the history of cinema.

Keywords: Şakir Seden, Republic Era, History of Cinema, Educational Policies

Yıldız, M. (2021). "Cumhuriyetin Illk Yıllarında Milli Eğitim Politikalarında Bir Araç Olarak Sinemanın Kullanılması: 1925 Şakir Seden Raporu”, Journal of Academic Value Studies 7(1) (2021) 41-51 (http://dx.doi.org/10.29228/javs.49535).

\footnotetext{
*E-mail address: muratyildiz@aksaray.edu.tr
} 


\section{Giriş}

19. yüzyılın sonlarında yaşanan teknolojik gelişmeler neticesinde bilimsel bir icat olarak ortaya çıkıp genel itibari ile bir eğlence aracı olarak kullanılan sinema, zamanla geniş insan kitlelerine ulaşabilen, siyasi ve kültürel mesajların da aktarıldığı bir iletişim aracı haline gelmiştir. Kültürel bir etkinlik olarak sinema, aynı zamanda bir sosyalleşme aracı olarak da insan yaşamındaki yerini alarak günümüze kadar ulaşmaktadır. İlk dönemlerde saniyede 16, sonraki yıllarda 24 fotoğraf karesinin insan gözü önünden hızlı bir şekilde geçirilmesi mantığına dayanan sinema, Fransızca, Cınematographe kelimesinden Türkçeye sinematograf olarak geçmiş olup kısaca sinema adıyla anılmıştır. Önceki dönemlerde artarda resim çekebilen cihazlar icat olunmuş ancak bu resimlerin hareketli olarak izlenebilmesi henüz mümkün olmamışır (Betton, 1995: 5-6). 1890 yılına gelindiğinde Thomas Edison, şerit film üzerine kaydedilen seri çekilmiş görüntülerin hareketli olarak izlenebilmesini sağlayan kinetoskop adı verilen bir cihaz geliştirmiş ancak bu cihaz sadece bir kişinin izleyebileceği şekilde tasarlanmıştır (Yurdigül ve Elitaş, 2013: 46). 1895 yılında Lumier Kardeşlerin görüntülerin beyaz perdeye aktarılarak topluca izlenmesini sağlayan sinematograf makinesini icat etmesiyle günümüz sinemasının temeli atılmıştır (Gökmen, 1989: 12). İlk zamanlarda daha çok konusu olmayan ve bir olayı sadece görüntü olarak aktaran sinema, sonraki dönemlerde oynanan tiyatro oyunlarının ve yazılan edebi eserlerin beyaz perdeye aktarılması ile yeni bir boyut kazanmıştır (Bazin, 2011: 63). Ilk çıkışı bilimsel bir buluş şekilde olan sinema, olayların, olguların ve düşüncelerin sesli ve görüntülü olarak ifade edilebildiği bir sanat dalı olarak izleyiciye yansıttığı duygusal aktarımların yanı sıra, belirli bir fikri aşılama yönüyle de kitleleri belirli düşüncelere yönlendirmenin bir aracı olmuştur. Bu yönüyle sinema, zamanla usta yönetmenlerin eliyle insanların vazgeçemediği, duygusal ve düşünsel aktarımların sanata dönüştüğü bir mecra olmakla birlikte ideolojik çıkarımların da yapılabildiği siyasal bir iletişim aracı olarak da karşımıza çıkmıştır. Ryan ve Lenos'a (2012) göre sinema, sadece bir görüntü yığını olmaktan ziyade kurulan oyun seti, oyuncuların büründüğü rol ve kameranın konumlandırıması ile sadece bir öykü anlatmanın ötesinde bir "anlam" taşımaktadır. Bu yönüyle sinema, bir eğlence aracı olmaktan çıkarak izleyici üzerinde kalııı tesirler bırakan bir sanat eserine dönüşmektedir. Sinemanın bir propaganda aracı olarak kullanılması fikri, devletlerin sinemaya olan yaklaşımlarında belirleyici ve yönlendirici bir rol üstlenmelerine imkân vermiştir. Bu bakımdan siyasi otoriteler, sinemayı kimi zaman ulusal çıkarları doğrultusunda bir propaganda aracı olarak kullanırken kimi zaman da milli birliğe ve ulusal çıkarlara aykırı, muhalif bir girişim olarak değerlendirerek müdahale etmişlerdir.

Dünya tarihinde sinemanın bir propaganda aracı olarak kullanılması çokça karşılaşılan bir durum olsa da, bu durumun etkili biçimde sistematik olarak kullanılmasına Bolşevik Devrimi ile rastlanmaktadır. Bolşevik Devrimi sonrasında kurulan geçici hükümet, halk nezdinde meşruiyeti sağlayabilmek ve yeni rejimi halk nezdinde sempatik göstermek amacıyla 1918 yıında "Elele Vermek" adıyla bir film çektirerek ülke geneline dağıtmıştır (Sadakoğlu, 2020: 118). Böylece sinema, devlet politikalarının bir gereği olarak halka belirli bir ideolojiyi aktarmanın bir yolu olarak öne çıkmaya başlamıştır. 1919 yılına gelindiğinde ise Rusya'da faaliyet gösteren sinemalar Lenin'in direktifiyle devletleştirilerek, rejimin kontrolü altına alınmıştır. Devrimin lideri Lenin, sinemaya verdiği önemi 1920' de Eğitim Bakanı Lunaçarsiky'ye yöneltmiş olduğu şu sözlerle ifade etmiştir (Pudovkin, 1966: 8): "İ̧̧leriniz iyi bir örgütlenmeyle yürümeye başladığı, memleketin durumu düzeldiği vakit bazı ödenekler alacaksınız. Film yapımını genişletmeli, özellikle sinemayı kitlelere ulaştırmalı, kentlere, en çok da köylere sokmalısınız. Siz ki sanat koruyucusu geçinirsiniz, bütün sanatlara içinde sizin için en önemlisinin sinema sanatı olduğunu hatıınızdan çıkarmamalısınız..." Eğitim Bakanı Lunaçarsiky'ye yöneltilen bu sözler, Lenin'in sinemanın halk üzerindeki etkilerini kavramış bir lider olduğunu ortaya koymakla birlikte sinemanın şehirlere ve özellikle köylere ulaştırılması ile gösterilen filmler aracılığı ile sosyal, kültürel ve ideolojik aktarımlarla toplumun genelinin arzu edilen forma büründürülmesine katkı sunan bir araç olarak görüldüğünü de ortaya koymaktadır.

Cumhuriyet Dönemi'nde yapılan reformların şekillenmesinde belirleyici bir unsur haline gelen ve etkileri hemen her alanda hissedilen Batılılaşma sürecinde, eğitim politikaları da gözden geçirilerek, laik ve çağdaş bir eğitim sistemi oluşturulması temel gayeler arasında yer almıştır. Türkiye Cumhuriyeti'nin kurucu kadrosunun savaş yıllarında bitap düşmüş, ekonomik olarak tükenmiş, çoğu okuma yazma bilmeyen ve kendi yaşadığı şehrin hatta köyün bile dışına çıkamamış bir toplumu, muasır medeniyetler seviyesine çıkarabilmesi, kolay bir iş olmamıştır. Çağdaşlaşma sürecinin en önemli araçlarından biri olan eğitimin modernleştirilmesi amacıyla yabancı uzmanların görüşlerine başvurularak yeni yetişecek nesillerin modern dünya şartlarına ayak uydurabilecek bir anlayışta yetiştirilmesi amaçlanmıştır (Şahin, 1998: 12). Dönemin yetkilileri, sinemanın çağdaş milli eğitim sisteminin oluşturulması ve geliştirilmesi açısından bir araç olarak kullanılabileceğini düşünmüş olacak ki, dönemin sinema konusunda uzman isimlerinden olan Şakir Bey'den sinemanın 
Milli Eğitim politikalarına nasıl hizmet edebileceği ve bu konuda yapılacak faaliyetlerin maliyeti üzerine bir rapor hazırlamasını istemiştir.

Bu çalışmanın konusu, cumhuriyetin erken dönemlerinde sinemanın milli eğitim politikalarında bir araç olarak kullanılmasının gündeme getirilmesi ve Şakir Seden'in konuya ilişkin 1925 yııında hazırladığı raporun incelenmesini esas almıştır. Çalışmanın amacı ise Seden'in hazırladığı rapordan yola çıkarak dönemin devlet politikalarının bir parçası olarak milli eğitim alanında sinemanın ne şekilde değerlendirilmeye çalışıldı̆ıın ortaya koymaktır. Bu bakımdan devletin izlediği milli eğitim politikaları doğrultusunda sinema kavramının bir araç olarak kullanıldığını ortaya koyan doğrudan bir çalışmaya rastlanılmamış olup, bu çalışma ile bu boşluğun doldurulması amaçlanmıştır. Ali Karadoğan editörlüğünde hazırlanan eserde (2019) olduğu haliyle transkripsiyon olarak verilen ve sinema tarihi çalışan araştırmacıların bilgisine sunulmuş olan bu rapor, bu çalışma ile cumhuriyetin erken yıllarında sinemanın eğitim, kültür ve siyaset ile olan ilişkisine de değinilerek disiplinler arası çalışan araştırmacıların da istifade edebileceği bir çalışmaya dönüştürülmüştür. Çalışmada öncelikle Osmanlı ve Cumhuriyet arşivlerinin yanı sıra Meclis Tutanakları, hatıratlar, konuya ilişkin yazılan tetkik eserler de incelenerek cumhuriyetin kuruluş yıllarında okullarda ve halkın eğitimi noktasında sinemanın bir araç olarak kullanılma girişimi izah edilmeye çalışmışır.

\section{Osmanlıdan Cumhuriyete Türk Sinemasının Ortaya Çıkışı}

Osmanlı toplumsal hayatına sinemanın girişinden önce halka açık gösteri mahiyetinde orta oyunları, KaragözHacivat gösterileri ve tiyatrolar, kültürel ve sanatsal bir etkinlik olarak görülmekteydi. Orta oyunları, daha çok doğaçlama tekniklerle güldürüyü esas alan gösteriler olmakla birlikte Karagöz ve Hacivat gösterileri ise beyaz perde kavramının ilk hali olarak daha ziyade Müslim tebaanın icra ettiği sosyal ve kültürel bir gelenek halinde uzun yıllar bir eğlence aracı olarak kullanılagelmiştir. Tiyatro gösterileri ise genel itibari ile İstanbul, İzmir gibi büyük kentlerde öne çıkan ve daha çok gayrimüslim tebaanın meşgul olduğu bir sanat dalı olarak karşımıza çıkmaktadıra. Osmanlı'nın eğlence merkezi sayılabilecek Beyoğlu, gayrimüslimlerin öncülüğünde sanatsal faaliyetlerin merkezi olmakla birlikte sinemanın da ilk gösterildiği mekânlar olarak karşımıza çıkmaktadır. Sinemanın Osmanlı sınırlarına girişinin ilk kez Sultan II. Abdülhamid adına Yıldız Sarayında düzenlenen bir gösteri ile gerçekleştiği ifade edilmektedir (Özgüç, 1990: 7; Gökmen, 1989:13; Özön, 1968a: 41). Osmanlı Dönemi'nde sinematografiye ait ilk arşiv belgesi ise 19 ağustos 1896 tarihinde Fransız Mösyö Jamin'in "hareket-i insaniye ve hayvaniyeyi gösteren sinematograf tabir olunan" yeni icat için ihtiyaç duyduğu elektrik lambasının muayenesine ilişkin gümrük işlemlerine ait belgedir (Cumhurbaşkanlığı Devlet Arşivleri Başkanlığı, Osmanlı Arşivi (BOA), BEO 829/62116: H. 10.03.1314). Bu belgeden anlaşılacağı üzere Osmanlı Dönemi'ne ait halka açık sinema gösterimi için ilk teşebbüs gerçekleştirilmiştir. Osmanlı Dönemi'nde ilk halka açık sinema gösterimleri ise 1897 yılında Polonyalı Yahudi Sigmund Weinberg tarafından icra edilmiştir (Özön, 1968a: 41). Sinema filmlerinin kıraathanelerde Karagöz ve Hacivat gösterilerinde kullanılan beyaz perdenin üzerine yansıtılarak gösterilmesi, halkın sinemaya alışmasını kolaylaştırmıştır (Gökmen, 1989: 16). Sultan Abdülhamid, tiyatroya olduğu gibi sinemaya da ilgi duymuş ve bu ilgisini Berlin'den getirttiği sinema filmleri ile gidermiştir. Ancak bu filmler, günümüz sinema filmleri gibi bir hikâyeyi esas alan filmler olmaktan ziyade askerlerin yüzme talimleri, buz üstünde gemicilik ya da bir devlet merasimi ve benzeri kısa görüntülerden oluştuğu bilinmektedir (BOA, Y. PRK. EŞA. 40/1: 03.01.1320).

Zaman içerisinde sinematograf faaliyetlerinin yaygınlaşarak ticari bir boyuta ulaşması ve sinema çekimlerinin devlet kontrolü altına alınarak muzır görülen çekimlerin önüne geçilmesi gibi sebeplerle 23 Mart 1903 tarihinde bir sinemacılık ile ilgilenen Ahmed ve ibrahim Beyler tarafından bir imtiyazname taslağı hazırlanmıştır. Buna göre, sinema gösterimi faaliyetleri gelişi güzel olmaktan çıkarılarak devlet kontrolünde gerçekleştirilmesi ve Osmanlı sınırlarında sinematograf işiyle meşgul olacak olan şirketlerin bir defaya mahsus olmak üzere devlete 10 bin lira ödemesi taslakta öne çıkan maddeler arasında yer almıştır (BOA. Y. PRK. AZJ, 46/16: H.0.12.1320). Böylece herkesin sinema gösterimi yapmasının önüne geçilerek sinematograf faaliyetlerinin belirli kurallar dâhilinde ve yetkilendirilmiş şahıslar tarafından yapılması karara bağlanmıştır. Bununla birlikte padişah suretlerinin sinemalarda gösterilmemesi, sakıncalı resimlerin gösterilmemesi, anarşistliğe dair filmlerin yasaklanması ve toplum ahlakını bozacak sinemaların gösterilmemesi gibi sinema konusunda ilk sansür uygulamaları da görülmektedir (Başbakanlık Devlet Arşivleri Genel Müdürlüğü, 2015: 358370). Sinemanın bir propaganda aracı olarak kullanılması görüşü ise ilk olarak 13 Aralık 1913 tarihinde Balkan Savaşları sırasında Türk halkının uğradığı zulümlerin sinemaya aktarılması düşüncesinin gündeme getirilmesi ile olmuştur. Rumeli

\footnotetext{
a Bu konuda ayrıntılı bilgi için bkz. Başbakanlık Devlet Arşivleri Genel Müdürlüğü, Osmanlı Arşivi Daire Başkanlığı. (2015). Arşiv Belgelerine Göre Osmanlı’ da Gösteri Sanatları. Haz. Resul Köse \& Muzaffer Albayrak. İstanbul: Bion Matbaacılık.
} 
Muhacirin-i İslamiye Cemiyeti Genel Sekreteri Hüsamettin Bey, Dâhiliye Nazırı Talat Bey’e yazdığı yazıda Balkan Savaşları sırasında Türklerin uğradığı zulümlerin sinema filmi olarak çekilmesi amacıyla Sigmund Weinberg'e izin verilmesini ve bölgede çekimler yapılması istemiştir (BOA, DH. KMS 63/49: H. 14.01.1332). Bu durum, aslında Bulgar Prensliği'nin 1903 yııında ortaya attığı Makedonya Sorununu Avrupa'ya taşınması için çekilen sinema filmine geç de olsa bir misilleme hareketi olmuştur (Özuyar, 2008: 12).

Osmanlı'da sinema, ilk zamanlarda seyyar olarak geçici mekânlarda gösterilirken, ilk yerleşik sinema ise 1908 yııında açılan "Pathe Sineması" adıyla açılmış, ardından Eclair (1909), Orıental, Cınema Thıeatre (1910), Central (1911), Orıentaux (1912), Gaumont, Lion (1913), Cine Palace, Magic (1914) ve Variete (1915) sinema salonlarının açılması ile yaygın hale gelmiştir (Gökmen, 1989:15). Böylelikle sinema, kendine has salonlarda gösterilmeye başlanarak sinema salonu kültürünün oluşması sağlanmıştır. Sinema, ilk ortaya çıktığında sadece erkeklerin katılabildiği sosyal ve sanatsal bir etkinlik iken, 1908 yılından itibaren haftanın belirli günleri kadınlara ayrılarak toplumsal tabana yayılması sağlanmıştır. Kısa bir süre sonra sinemanın kadınlar ve erkeklerin haremlik-selamlık olarak araya paravan çekilmek ya da kadın ve erkekleri sağlı-sollu, önlü-arkalı oturtmak suretiyle birlikte izlemelerine müsaade edilmiş, Cumhuriyet Dönemi'nde bu usul terk edilerek karma sinemalara geçilmiştir (Akman, 1989: 17; Özgüç, 1990: 14,15). 1914 yılı Türk sineması için bir dönüm noktası olmuştur. Bu döneme kadar Osmanlı'da gösterimi gayrimüslimlerin hâkim olduğu bir sektör iken, 19 Mart 1914 tarihinde Murat ve Cevat Beyler tarafından "Milli Sinema" adıyla ilk yerli sinema salonu açılmış (Gökmen, 1989:15), ardından yine aynı yıl Kamil ve Şakir Seden kardeşler tarafından "Kemal Film" kurularak sinema salonlarında ithal filmler izletilmiştir (Soysüren ve Yıldız, 2017: 93). Sinema sektörüne işletmeci olarak da olsa Türk girişimcilerin dâhil olması, sektörde millileşme adımlarının ilk basamağını oluşturulması açısından oldukça önemli bir adım olmuştur. Yine 1914 yılında Sigmund Weinberg'in yanında yetişerek sinema projeksiyon cihazını kullanılmasını öğrenmiş olan Fuat Uzkınay adlı yetenekli Türk genci, zamanla kamera kullanmasını da öğrenerek ilk yerli filmin çekilmesini sağlamıştırb. Rusların 93 Harbi sırasında Yeşilköy'e diktikleri zafer anıtının Birinci Dünya Savaşı'nın başlaması ile dinamitle patlattırılarak yıkılmasına karar verilmiş ve bu tarihi anın kamera aracılığı ile kayda geçirilmesini isteyen Türk yetkililer ilk olarak yabancı bir şirketle anlaşmışır. Ancak bu önemli anın bir Türk tarafından kayda alınmasının daha uygun olacağı kanaatine varılmış ve yapılan araştırmalar neticesinde o dönemde yedek subay olarak orduda görev yapan Fuat Uzkınay’a ulaşımışır. Ancak Uzkınay, sinema projeksiyon cihazını kullanmayı bilmekle birlikte kamera kullanımını bilmemektedir. Uzkınay, kısa sürede yabancı teknisyenlerden kamera kullanımını öğrenmiş ve bu anı kamera ile çekmeyi başarmıştır. Böylece ilk yerli belgesel filmi olan "Ayastefanos'taki Rus Abide'sinin Yıkıışı" 14 Kasım 1914 tarihinde 150 metrelik şerit halinde çekilerek tarihteki ilk Türk filmi olma özelliğine sahip olmuştur (Özgüç, 1968: 268).

Osmanlı Dönemi'nde sinemaya ilişkin kurumsal bir adım da Harbiye Nazırlığı ve Erkan-ı Harbiye-i Umumiye Riyaseti (Genel Kurmay Başkanı) görevlerini üstlenmiş olan Enver Paşa tarafından atılmıştır. Almanya'ya giden Enver Paşa, burada ordu tarafından çekilen filmleri izlemiş ve sinemanın okuma yazma bilmeyen halk kitleleri üzerinde oldukça etkili bir araç olduğu kanaatine varmıştır. Bu nedenle ülkeye döner dönmez ordu bünyesinde bir sinema biriminin açılması çalışmalarına başlamıştır. Bu amaçla 1915 yııında "Merkez Ordu Sinema Dairesi" kurulmuş ve başına Weinberg, yardımcısı olarak da Fuat Uzkınay atanmıştır. Bu birimin görevi, Türk ordusuna ilişkin propaganda filmlerinin çekilmesi olmuştur. Merkez Ordu Sinema Dairesi bünyesinde, Osmanlı Devleti'nin askeri harekâtlarına ilişkin çok sayıda film çekilmiştir (BOA, MF. MKT, 1230/37: H. 16.12.1335). Ancak Birinci Dünya Savaşı sonrasında imzalanan Mondros Mütarekesi sonrasında itilaf devletleri tarafından Sinema Dairesi bünyesindeki çekilen filmlere, çekim malzemelerine el konulmasının önüne geçebilmek amacıyla Sinema Dairesi kapatılarak söz konusu filmlerin ve sinema çekimine ilişkin araç-gereçlerin devredilmesi gündeme gelmiştir. 22 Kasım 1919 tarihinde Sultan Vahdeddin iradesi ile Maliye Nezareti'ne yazılan yazıda, Merkez Ordu Sinema Dairesi bünyesindeki tarihi eser niteliğinde olan sinema filmlerinin Askeri Müze'ye, sinema araç-gereçlerinin de Malul ve Gaziler Cemiyeti olarak bilinen Ma'lûlîn-i Guzât-ı Askeriye Muavenet Hey'eti'ne devredilmesine karar verilmiştir (BOA, DUiT. 166/19: H. 28.02.1338). Devir işlemleri sonrasında

\footnotetext{
b Uzkınay'ın sinema sektörüne girişi ise biraz kader, biraz da yeteneği sayesinde olmuştur. Osmanlı'nın bilinen ilk sinemacısı olan Weinberg, İstanbul Sultanisi'nde dönem dönem öğrencilere sinema filmleri göstermekte olup, Fizik Laboratuvarında tekniker olarak görev yapan Uzkınay ise Weinberg'e film tertibatını kurmasında yardımcı olmaktadır. Uzkınay, Weinberg'e asistanlık yaparken aynı zamanda sinema projeksiyon makinesini kullanmayı da öğrenmiştir. Daha sonra okul müdürü Muhsin Kemal Bey’i bu işleri kendisinin yapabileceğini söyleyerek bir sinema projeksiyon makinesi alınmasına ikna ederek sinema makinistliğine giriş yapmıştır. İleride de değinileceği üzere çalışmaya konu olan ve aynı okulda tarih öğretmenliği yapan Şakir Seden ise gösterilecek filmlerin seçilmesi konusunda kendisine yardım etmeye başlamış ve ileriki yıllarda Türk sinemasının gelişmesinde önemli bir rol oynamıştır.
} 
cemiyet çatısı altında sinema faaliyetleri, Fuat Uzkınay'ın öncülüğünde gerçekleştirilmiş ve Uzkınay idaresinde yerli filmler çekilmeye başlanmıştır (Odabaş, 2006: 206,207).

Yerli imkânlarla meydana getirilmeye çalışılan Türk sineması, I. Dünya Savaşı́nın gölgesinde ilk ürünlerini ortaya koymaya başlamıştır. 1916 yılında kurulan "Müdafaa-i Milliye Cemiyeti" adıyla kurulan kuruluş, gelirlerini arttırabilmek adına film yapımı işlerine girişmiştir. Cemiyetin himayesinde ve Sedat Semavi'nin yönetmenliğinde ilk öykülü Türk filmi olan Pençe(1916) ve Casus (1917) filmleri çekilmiştir. Savaş sonrasında kurulan Malul ve Gaziler Cemiyeti bünyesinde ise 1919 yılında "Mürebbiye" ve "Binnaz" filmleri çekildikten sonra 1921 yılında ise "Bican Efendi Vekilharç" filmi çekilirken Kurtuluş Savaşı sonunda ise 1922 yılında İstiklal-İzmir Zaferi filmi çekilmiştir (Özön, 1968b: 269). Kemal Film'i kurarak sinema işletmeciliği yapan Seden kardeşler, 1922 yılına gelindiğinde film yapımcılığı işine de girerek 1922-1924 yılları arasında "İstanbul'da Bir Aşk Faciası", "Boğaziçi Esrarı", "Ateşten Gömlek”, "Kız Kulesi Faciası", "Leblebici Horhor" ve "Sözde Kızlar" adıyla 6 adet yerli film çekmişlerdir (Arpad, 1968: 289). Bu döneme damgasını vuran ünlü yönetmen Muhsin Ertuğrul olmuştur. Küçük yaşlarda oyunculuğa başlayan Ertuğrul, yurt dışında başladığı yönetmenliğe Türkiye'de devam etmiştir. Seden kardeşlere ait Kemal Film bünyesinde çektiği filmlerle adını duyuran Ertuğrul, cumhuriyetin ilanından kısa bir süre önce Halide Edip'in romanından uyarlanan ve ülke genelinde büyük coşku yaratan "Ateşten Gömlek" filmini çekerek Türk sinema tarihine adını yazdırmıştır (Sevim, 2016:68). Ertuğrul'un çektiği bu film, kurtuluş savaşını konu alarak Türk milletinin büyük yokluklarla göstermiş olduğu başarıyı beyaz perdeye aktarması ve milli duygulara hitap ederek halkın büyük beğenisini kazanmasıyla Türk sinemasında ayrı bir yere sahip olmuştur. Seden kardeşler ise bir süre sonra sinema yapımcılığı işini terk ederek yeniden sinema işletmeciliğine dönüş yapmışlardır (Arpad, 1968: 289).

Osmanlı'da sinemanın bir eğitim aracı olarak kullanılması girişimine ise 22 Eylül 1917 tarihli bir arşiv vesikasında rastlanmaktadır. Buna göre, Maarif Nezareti'nde ressam olarak görev yapan Necati Bey, okullarda öğrencilere izletilmek üzere tarih ve coğrafya konulu sinema filmleri çekmek üzere Kastamonu'ya gönderilmiş ve valilik tarafından kendisine gerekli kolaylığın gösterilmesi istenmiştir (BOA, MF. MKT. 1229/120: H. 05.12.1335). Necati Bey, Anadolu” ismini verdiği filmi tamamlamış ve Maarif Nezareti aracılığı ile 19 Mart 1918 tarihinde işlenerek çoğaltılması için Merkez Ordu Sinema Dairesi'nden gerekli izni almıştır (BOA, MF. MKT. 1233/8: H.06.06.1336). Sinemanın eğitimde kullanımına ilişkin bir diğer girişim ise Merkez Ordu Sinema Dairesi tarafından I. Dünya Savaşında Osmanlı ordusunun askeri harekâtlarına ilişkin çekilmiş olan filmlerin askeri öğrencilere izletilmesidir. 24 Eylül 1917 tarihinde Dersaadet Merkez Kumandanı Cevat Paşa imzasıyla Maarif Nezaretine gönderilen yazıda Merkez Ordu Sinema Dairesi tarafından çok sayıda film çekildiğini ve bu filmlerin harp okullarındaki askeri öğrencilere izlettirilmesi istenmiştir. Böylelikle öğrencilerin askerlik mesleğine olan meyillerinin ve vatan sevgilerinin artacağı belirtilmiştir. Sinema filmlerinin makul bir ücret karşıllğında izletilerek Merkez Ordu Sinema Dairesinin de gelişmesine katkı sunulacağı dile getirilmiştir (BOA, MF. MKT, 1230/37: H. 16.12.1335).

\section{Cumhuriyet Dönemi Milli Eğitim Politikalarında Sinemanın Kullanılma Girişimi ve Şakir Seden Raporu}

Osmanlı Dönemi'nde daha çok gayrimüslimlerin etkin olduğu sinema sektörü, zamanla konuya aşina olan yerli yapımcı ve yönetmenlerin eliyle millileştirilmeye çalışılmış ise de bu durum biraz zaman almıştır. Zira sinema, beyaz perdeye yansıyana kadar yapımcı, yönetmen, senaryo, oyuncu, ışı, ses, kostüm ve makyaj ve benzeri birbirinden farklı pek çok teknik ve sanatsal uzmanlık gerektiren bir sektör olması nedeniyle bu kadar yetişmiş kadronun bir anda oluşması mümkün olmamıştır. Bu nedenle milli sinemanın tam manasıyla oluşması ileriki yıllarda gerçekleşmiştir. Sinemanın halk üzerinde etkileyici bir unsur olduğunun anlaşılması, sinemaların bir propaganda aracı olarak kullanılmasını gündeme getirmiştir. Bununla birlikte filmlerin, mevcut rejime aykırı ve toplumsal değerlerle çelişir mahiyette olmamasına özen gösterilmesi, siyasi otoritenin mevcut düzeni koruması ve bu düzenle barışık bir toplum inşa etmesi açısından sinema filmlerine müdahale edilmesi düşüncesini de ayrıca doğurmuştur. Bu noktada bazı propaganda filmlerinin çekilmesi ve bazı filmlerin ise yasaklanması, Osmanlı Dönemi'nden itibaren görülen bir uygulama olarak ortaya çıkmaktadır. Bu noktada sinema filmlerinin yönlendirilmesi ve denetim altında tutulması da milli eğitim politikalarının bir parçası olarak görülmüştür.

Cumhuriyet Dönemi'nde sinema filmlerine siyasi reflekslerle müdahale edilmesi örneğine 29 Mayıs 1923 tarihinde İzmir'deki sinemalarda filmlerin başlamasından önce gösterilen itilaf devletlerinin resmi geçit ve manevralarını içeren reklam mahiyetindeki görüntülerin yasaklanması ile rastlanmışır. Bu görüntülerin halkın moral ve motivasyonunu bozacağı gerekçesiyle Anadolu'daki sinemalarda gösterilmesinin yasaklanması yönündeki resmi yazılara arşiv vesikaları arasında rastlanmıştır (BCA, 30.10.0.0/146.43.3). Buradaki temel amaç, kesintiye uğrayan Lozan görüşmelerinin yeniden başladığı bir dönemde anlaşmaya varılamaması durumunda savaşın bir seçenek olarak hala geçerliliğini koruması 
nedeniyle itilaf devletlerinin sahip olduğu askeri gücün halk üzerinde olumsuz tesirler bırakmasının önüne geçilmesi olmuştur. Bu reklamların varlık nedeni ise o dönemde sinemalarda gösterilen filmlerin yurt dışından ithal edilen filmler olması ve bu filmlerin başına bu tarz siyasi ve askeri propagandalar içeren görüntülerin film şeritlerine eklenmesi olarak ifade edilebilir. O dönemde gösterilen sinema filmlerine yönelik bir eleştiri de dini ve toplumsal açıdan önemli bir yer tutan Diyanet işleri Reisliğinden gelmiştir. 22 Nisan 1924 tarihinde Diyanet İşleri Reisliği tarafından halkın dini ve milli duygularını rencide edecek filmlere müsaade edilmemesi konusunda Başbakanlığa bir yazı yazıımıştır (BCA, 30.10.0.0/86.566.9). Yazıda:"Sinemalarda hissiyat-ı dini ve milli rencide ve hiçbir sınıfın tezyif ve tahkiri maksadı takip edilmeyerek tamamıla vatani, dini, milli ve ahlaki olmak esas iken, bazı müesseselerin bu esastan inhiraf ederek garazkârâne bir tarafın hayatını rencide, bir sınıfı tezyif maksadıyla temsiller yapıldığı maalesef işitilmektedir..." sözlerine yer verilmiş olup filmlerde ilmiye sınıfına yönelik rencide edici tavırların yasaklanmasına değinilmiştir. Türk Sinemasında sıkça rastlanılan bir olgu olarak din adamlarının din istismarı yapan, çıkarcı kişiler olarak beyaz perdeye yansıtılması, o dönemde de mevcut olup bu durum, Diyanet İşleri Reisliğince eleştirilmiş ve bu duruma müdahale edilmesi amacıyla söz konusu yazı Başbakanlık makamına iletilmiştir.

Cumhuriyet Dönemi'nde sinema filmlerinin bir propaganda aracı olarak kullanılması, cumhuriyetin ilanı öncesinde Türkiye Büyük Millet Meclisi (TBMM) döneminde Karesi Mebusu Vehbi Bey tarafından gündeme getirilmiştir. 22 Ocak 1920 tarihinde yapılan meclis görüşmelerinde gündeme gelen Yunanlıların Yenişehir civarında yaptıkları mezalim konusunun görüşülmesi sırasında söz alan Vehbi Bey, yapılan bu zulümlerin film ve fotoğraflar ile kayda alınarak yaşanılan acı tecrübelerin dünyaya duyurulması ve sonraki nesillere aktarılmasının yerinde bir karar olacağını ifade etmiştir (TBMM Tutanak Dergisi (TD), Dönem (D) 1, Cilt (C) 6, Birleşim (B) 101, Oturum (O) 2: Rumi (R) 22.11.1336). Böylelikle Cumhuriyet Dönemi'ne geçişte sinemanın bir propaganda aracı olarak kullanılması fikri ortaya atılmıştır.

Türkiye'de sinema filmlerinin halkın eğitiminde bir araç olarak kullanılması fikri ilk olarak Şark Orduları Komutanı Kazım Karabekir Paşa tarafından 1923 yııında TBMM Riyaset-i Celilesine sunduğu bir tezkere ile gündeme gelmiştir. Kazım Paşa, sinemanın önemini anlatan ve hükümetin bu konuda atması gereken adımları ihtiva eden "ibret Yeri" adıyla bir proje hazırlayarak, TBMM'ye sunmuştur. Bu projeyi maddeler halinde arz eden Kazım Karabekir, ilk olarak İstanbul, İzmir gibi bazı merkezlerde gösterilecek filmlerin zabıta-i ahlak ya da maarif memurları tarafından incelenerek Türk aile yapısına ve ahlaki yaşantısına uygun olup olmadıklarının kontrol edilmesini ve uygun olmayanların sinema salonlarında gösterilmemesi gerektiğini ifade etmiştir. Bununla birlikte ikinci olarak da yeni sinema salonlarının yapılarak sinema kültürünün yurt genelinde yaygınlaşmasına işaret etmiş ve bu konuda Hilal-i Ahmer ve Türk Ocağı benzeri kuruluşlardan destek alınması gerektiğini belirtmiştir. Ayrıca milli sinemanın vücuda getirilebilmesi için elzem olan sinema mekteplerinin, hükümet ve belediyelerin kendi aralarında dengeli bir yardımlaşması neticesinde oluşturulması gerektiğini de sözlerine eklemiştir. Kazım Paşa, sinemaların halkın eğitilmesinde önemli bir araç olduğunu ve bu aracın etkili bir biçimde kullanılması gerektiğini ifade etmiştir (Cumhurbaşkanlığı Devlet Arşivleri Başkanlığı, Cumhuriyet Arşivi $(B C A), 30.10 .0 .0 / 146.43 .5)$. Ancak Kazım Paşa'nın bu projesi maddi yetersizliklerden dolayı hayata geçirilememiştir. Kazım Paşa, ayrıca 25 şubat 1925 tarihinde TBMM'de yapılan bütçe görüşmeleri esnasında gündeme gelen Maarif Vekâleti bütçesi müzakerelerinde söz alarak Türkiye'nin eğitim politikaları hakkında görüşlerini ifade ederken sinemanın eğitim üzerindeki etkilerine de değinmiştir. Kazım Paşa, okullarda her konunun pratik bir şekilde öğretilmesinin mahzurlu olduğunu, bu bakımdan eğitimde uygulamalı ve görsel metotlardan da istifade edilmesi gerektiğini ifade etmiştir. Ardından sinemanın eğitimde gerekli olduğunu şu sözlerle dile getirmiştir (TBMM TD, D. 4, B. 64, O. 1, R. 25.2.1341): "...Avrupa, Amerika gibi göremeyeceği hayat âlemini de sinema filmleriyle göstermeli. Bunun için maarifimizin bir de sinema kütüphanesi olmalı ve o filmleri bütün halka irae etmelidir. Avrupa'da, Amerika'da sanayi nasıldır, terakkiyat nedir, vapurları, şimendiferleri bütün bunları göstermek lâzımdır..." Kazım Paşa, halkın ve öğrencilerin görsel içerikli materyallerden istifade edebilmeleri için dünyanın farklı yerlerini anlatan sinema filmlerinin toplandığı merkezi bir sinema kütüphanesinin kurulması gerektiği ifade etmiş ve böylelikle bir film arşivinin de oluşacağını dile getirmiştir. Bir sinema kütüphanesinin kurulması görüşü, Şakir Seden'in aynı yıl yazmış olduğu raporda da dile getirilen konuların başında yer almıştır.

\subsection{Tarih Muallimi ve Film Mütehassısı Şakir Seden'in Hazırladığı Rapor}

Cumhuriyetin kuruluşu sırasında çağdaş medeniyetler seviyesine çıkarılmak istenen Türk toplumunun yapılacak reformlar eşliğinde modernleştirilmesi, o dönemin devlet politikalarında ele alınan başlıca konular arasında yer almıştır. Modernleştirme politikalarının uygulanmasında başat rol oynayan kurumlardan biri de şüphesiz Maarif Vekâleti olmuştur. Maarif Vekâleti, sınırlı bütçeler eşliğinde bir yandan yeni yetişen neslin modern dünya gereksinimlerine göre 
eğitilmesini üstlenirken, öte yandan da yetişkin bireylerin mesleki ve kültürel birikimlerinin arttırılmasından mesul olmuştur. Bu bakımdan büyük bir vazife üstlenen vekâlet, teorikte belirtilen modernleşme faaliyetlerinin pratiğe geçirilmesi hususunda bir takım arayışlar içerisine girmiştir. Cumhuriyetin ilk yıllarında Maarif Vekâleti, eğitim sisteminde yapılacak reformların ayrıntılı bir biçimde ortaya konulması ve eğitim konusunda bir metodolojinin belirlenmesi hususunda yerli ve yabancı uzmanların görüşüne başvurmuştur. Bu konuda istifade edilen yerli uzmanlardan biri de 1925 yııında sinemanın, öğrencilerin ve halkın eğitilmesi amacıyla bir araç olarak kullanılması konusunda Maarif Vekâletine rapor hazırlayan film mütehassısı ve tarih muallimi Şakir Bey olmuştur. Rapordan anlaşıldığı üzere süreç, Maarif Vekâletinin sinema konusundaki birikimi nedeniyle Şakir Bey'den böyle bir rapor hazırlamasını talep etmesiyle başlamıştır. Şakir Bey'in bu konudaki raporuna geçmeden önce konunun soyadı kanunundan önce gerçekleşmesi sebebiyle Şakir Bey'in kim olduğu konusunda değinmek yerinde olacaktır. Illk olarak üzerinde çalışılan arşiv belgesinde "Tarih Muallimi ve Sinema Mütehassısı Şakir Bey" dışında yazar hakkında başka bilgiye rastlanmamaktadır (BCA, 180.9.0.0/242.1212.29). Ancak o dönemde Şakir Bey olarak bilinen, tarih öğretmenliği yapan ve sinema ile meşgul olan insan sayısı az olacağından öncelikle sinema ile uğraşan Şakir isimleri üzerinde bir çalışma yapıımıştır. Ulaşılan ilk bilgilere göre raporu hazırlayan Şakir Bey'in İstanbul Sultanisinde Tarih Encümen Azası olan Şakir Bey olma ihtimali üzerine durulmuştur ( BOA, MF. IBT. 514/14: H. 12.10.1332). 1910 yılında İstanbul Sultanisinde fizik laboratuvarında tekniker olarak çalışan Fuat Uzkınay ve aynı okulun tarih öğretmeni Şakir Seden tarafından bir sinema gösterisi düzenlendiği bilgisinin tetkik eserlerde yer alması söz konusu Şakir Bey'in Şakir Seden olma ihtimalini güçlendirmiştir (Gökmen, 1989: 244; Özön, 1968a: 42; Filmer, 1984: 92). Yukarıda da değinildiği üzere kardeşi Kemal Seden ile birlikte kurdukları sinema şirketi aracılı̆̆ı ile Avrupa'dan film getirterek sinema işletmeciliği işine giren Şakir Seden, yaptıkları bu ticari faaliyetler sayesinde dönemin sinema konusundaki yerli uzmanları arasında sayılmalarını sağlamıştır. Rapordan da anlaşıldığı üzere Şakir Bey'in, hangi ülkede, ne tür filmlerin çekildiğini, bunların maliyetleri ve teknik ayrıntıları hakkında ayrıntılı bilgiye sahip olması, raporu hazırlayan kişinin Şakir Seden olduğunu ortaya koymaktadır.

Şakir Bey'in raporu, genel olarak sinemanın bir eğitim aracı olarak kullanılması için gerekli kurumsal alt yapının oluşturulması, eğitici filmlerin seçilmesi ve temin edilmesi, bu filmlerin merkezi bir kütüphanede arşivlenerek yurda dağıtılması ve yapılacak bu faaliyetlerin maliyetleri üzerinde durmuştur. Şakir Bey, ilk olarak sinemanın eğitici bir araç olarak kullanılması noktasında yapılması gerekenleri üç ana madde ile sıralamıştır. Buna göre; ilk olarak okullarda sinema salonlarının kurulması, okul olmayan yerlerde ise şehir ve kasaba sinemalarından istifade edilerek öğrencilere yönelik seansların tertip edilmesi konusuna değinilmiş̧ir. İkinci olarak da, sinemanın olmadığı şehir, kasaba ve köylerden yolları müsait olanlar için seyyar sinemalar aracılığı ile sinema gösterimlerinin yapılması gerektiği belirtilmiştir. Üçüncü olarak ise sinemanın Türklüğü ve Türk kültürünü öne çıkaracak bir propaganda aracı olarak kullanılması gerektiği ifade edilmiştir (BCA, 180.9.0.0/242.1212.29). Buradan anlaşıldığı üzere Şakir Bey'in Maarif Vekâletine sunduğu raporda atılması gereken öncelikli adımların başında sinemanın okullarda öğrenciler ile halkın eğitiminde ve Türk kültürünün tanıtımı noktasında bir araç olarak kullanılmasını sağlamak gelmektedir. Bu sıralamanın ardından Şakir Bey, ayrıntılara girerek konuyu ayrıntılı bir şekilde ele almaya başlamıştır.

Şakir Bey, öncelikle İstanbul'daki duruma değinerek İstanbul'da mevcut olan bazı okullarda sinema salonlarının ve sinema gösterimi için gerekli olan makine ve tertibatın bulunduğunu ifade etmiştir. Buna göre Galatasaray Lisesi, İstanbul Lisesi, Kız ve Erkek Muallim Mektepleri, Bahriye Mektepleri, yabancı okullar içerisinde Amerikan Kız ve Erkek Koleji ile bazı Fransız kolejlerinde sinema salonlarının bulunduğunu dile getirmiştir. Ancak bu sayısının yeterli olmadığını ifade eden Şakir Bey, taşrada da en uygun olanlardan başlanarak her yıl bir iki okulda sinema salonunun açılması gerektiğini belirtmiştir. Elektrik bulunan şehirlerde bu işin daha kolay ve daha ucuza mal edilebileceğini ifade eden Şakir Bey, gerekli tertibat ile bir sinema salonunun açılmasının 500-600 liraya mal olacağını belirtmiştir. Maarif Vekâletinin sinema kuramadığı yerlerde ise Türk Ocakları'na sinema açtırarak hem halkın hem de öğrencilerin istifadesine sunulmasının hayırlı ve faydalı olacağını dile getirmiştir. Bunu yanı sıra, küçük kasabalarda gösteri düzenleyen seyyar sinemaların bulunduğunu ve bunların öğrencilere ve halka sinema izlettiğinin bilindiğini ve bunların yapılacak bir düzenleme ile belirli mıntıkalara göre ayrılarak kamuya ait makineler ile birkaç program verilerek çeşitli şehir ve kasabalara gönderilmesinin yerinde olacağını ifade etmiştir (BCA, 180.9.0.0/242.1212.29).

Şakir Bey'in raporunda ele aldığı bir diğer konu ise sinemanın öğrencilerin dışında halkın da eğitimi hususunda kullanılması olmuştur. Türkiye'nin öncelikle bir tarım ülkesi olması nedeniyle, tarıma yönelik eğitici filmlerin gösterilmesinin yanı sıra Türk halkının yaşadığı ülke hakkında yeterli bilgiye sahip olmadığını ve bu bakımdan Türkiye'nin sahip olduğu diğer doğal güzellikler ile birlikte fotoğraflanarak coğrafya kitaplarına konularak halkın ve öğrencilerin 
istifadesine sunulması gerektiğini belirtmiştir. Ayrıca, Türkiye'de oldukça sık rastlanan tarihi eserlerin, doğal güzelliklerin, yöresel kıyafetlerin, çeşitli dini ve kültürel zenginliklerin filmlere kaydedilerek Türkiye'nin ve Türk kültürünün yurda ve dünyaya tanııııının sağlanabileceğini de belirtilmiştir. Bunun dışında çıkarılacak bir nizamname ile film şirketlerinin kültürel ve aile konulu filmleri getirmeye zorunlu kılınması gerektiğinin de altı çizilmiştir (BCA, 180.9.0.0/242.1212.29).

Şakir Bey'in değindiği bir diğer konu ise Kazım Karabekir Paşa'nın da dile getirdiği Maarif Vekâleti bünyesinde bir "Film Kütüphanesi" kurulması tavsiyesi olmuştur. Böylelikle yurdun dört bir tarafına gönderilecek filmlerin depolandığı ve arşivlendiği ulusal bir merkezin oluşması sağlanacaktır. Bu durumun gerekçesi olarak ise yurda sokulan filmlerin ticari amaçlar doğrultusunda daha çok halkın hoşuna gidecek aşk, macera ve eğlence konulu filmler olması ve bu filmlerin Maarif Vekâletinin arzu ettiği amaçlara hizmet edemeyeceği gösterilmiştir. Şakir Bey, Maarif Vekâletinin amaçları doğrultusunda ihtiyaç duyulan filmleri şu şekilde sıralamıştır (BCA, 180.9.0.0/242.1212.29):

- Okullarda eğitime katkı sunacak olan bilimsel, tabiat, hayat bilgisi, coğrafya, tarih, sanat ve zanaat temalı filmler,

- Meslek okullarına mahsus olan denizcilik, ormancılık, madencilik ve doğa bilimleri konulu filmler,

- Hem okullarda gösterilebilecek hem de halkın istifade edebileceği sağlık, toplumsal hayat, ziraat ve tarih konulu filmler.

Ancak bu filmlerin daha önce de değinildiği üzere film tedarikçileri tarafından tercih edilmediği, bu nedenle bu tarz filmleri yapan Avrupa ve Amerika menşeli şirketlerin hazırladığı filmlerin getirtilerek açılması tavsiye olunan film kütüphanesinde yer alması gerektiği vurgulanmıştır. Bu tarz filmlerin Fransa'da, Almanya'da ve Amerika'da bulunan şirketlerde çok sayıda yer aldığı ancak bu filmlere olan rağbetin fazla olması nedeniyle fiyatlarının da yüksek olacağı dile getirilmiş ve film şeritlerinin metresinin yaklaşık 3-4 frank karşılığında alınmasının mümkün olacağı da belirtilmiştirc Ayrıca aynı filmden birer kopya daha alınması durumunda imtiyaz ve inhisar bedelleri düşüldüğünde metresinin 1.25 frank (12-13 kuruşa) gelerek daha ucuza mal edilebileceği belirtilmiştir. Bu bağlamda, Maarif Vekâletinin toplamda gelecek yıl (1926 yılı kastedilmektedir) Avrupa filmlerinden 10 bin metrelik film getirtilmesini ve bu filmlerin maliyetinin 5 bin lira civarında tutacağını ifade etmiştir. Bu filmlerin 2.000 metresinin kültür, 2.500 metresinin coğrafya konulu filmler olup, bunların İstanbul dışında gösterilmesi durumunda nakliye masraflarının da eklenmesiyle filmlerin metresinin 1 liraya yükselerek maliyetlerin biraz daha artarak toplamda 5.000 lira civarında olacağı belirtilmiştir. Bunun dışında 5000 liralık bir bütçenin de okullardaki sinema salonlarının yapımına ayrılması gerektiği ifade edilmiştir. Şakir Bey, son olarak bu iş için 10.000 liralık bütçe ayrılarak bir süre sonra arzu edilen neticelerin alınabileceğini ifade etmiştir (BCA, 180.9.0.0/242.1212.29). Şakir Bey, raporunda devletin milli eğitim politikaları kapsamında okullarda sinema gösteriminin etkili bir eğitim aracı olarak kullanılmasının gerekliliğini ortaya koyduktan sonra yaptığı ayrıntılı hesaplarla bu işin devlete maliyetinin ne olacağını belirtmiştir. Şakir Bey, raporunda filmlerin nasıl, ne şekilde ve nereden temin edileceğinden, bu filmlerin konularının ne olacağına dek ayrıntıı bir rapor hazırlamış, bu konudaki alt yapı ve teknik donanım eksiliğine vurgu yapmıştır.

Milli Eğitim konusu, modern Türk toplumunun oluşturulma gayretleri arasında önemli bir yer edinmesine rağmen bu alanda yapılacak reformlar, devlet bütçesinin sahip olduğu imkânlar dâhilinde gerçekleşmiştir. Nitekim Şakir Bey, hazırladığı ikinci raporda bu konuya açıkık getirmektedir. Rapordan anlaşıldığı üzere, ilk raporunu tamamlayan Şakir Bey, Maarif Vekâletine sunmuş, vekâlet tarafından yapılan inceleme neticesinde bu işlere ayrılacak toplam bütçenin 5.000 lira olabileceği belirtilerek bu bütçeye uygun yeni bir rapor hazırlaması istenmiştir. Şakir Bey ise önceki raporunda hesapladığı 10.000 liralık bütçenin 5.000 liraya düşürülmesi karşısında durumu yeniden değerlendirmiştir. Şakir Bey, bu miktarın böylesi maliyetli bir iş için çok az bir para olduğunu belirttikten sonra bu bütçe ile başlangıç olarak numune sayılabilecek işlerin yapılabileceğinden bahsetmiştir. Bu bağlamda öncelikle ilk raporunda bahsettiği ve getirtilmesini tavsiye ettiği yabancı filmlerin bir kısmının getirilerek film kütüphanesinin kurulmasına başlanmasını tavsiye etmiştir. Bu bağlamda Avrupa'dan metresi 3 frank olmak üzere 10 bin metrelik ilmi, fenni ve zirai konulu filmlerin getirtilmesi halinde bunun 30.000 frank yani 3000 liraya denk geleceğini ifade etmiştir. Bu amaçla öncelikle filmlerin belirlenmesi için Avrupa ve Amerika'dan kataloglar getirtilerek gerekli incelemeler sonrasında karar kılınan filmlerin talep edilmesi gerektiği ifade edilmiştir. Şakir Bey, ilk olarak 500 metrelik coğrafya temalı numune filmlerin getirtilerek ìstanbul veya bir sahil şehrinden başlanarak izletilmesi gerektiğini tavsiye etmiş ancak yol masraflarının da eklenmesiyle filmlerin metresinin ortalama olarak 75 kuruşa çıkmasıyla 375 liraya mal olacağını belirtmiştir. Şakir Bey, ayrıca 500 metrelik kültür temalı filmlerin satın alınmasını ve bunun da 375 liraya mal olacağını dile getirmiştir. Ayrılan bütçenin 750 lirasının ise daha

\footnotetext{
c Burada satın alınan film fiyatlarının, film şeritlerinin uzunluğunun metre cinsinden çarpımıyla hesaplanarak belirlendiği anlaşılmaktadır.
} 
önceki raporunda belirttiği Türklüğün, Türk kültürünün tanıtımı ve propagandası için ayrılması gerektiğini belirttikten sonra kalan 1500 lira ile de sineması olmayan bir şehre sinema yapılmasını tavsiye etmiştir. Söz konusu bütçenin böylesine masraflı bir sektör için çok az bir para olduğunu ifade eden Şakir Bey, sonraki sene için bu işlere 10.000 liralık bir bütçenin ayrılmasının daha isabetli olacağını belirtmiştir. Şakir Bey, getirilen bu filmlerin kurulmasını tavsiye ettiği film kütüphanesinde toplanarak bu merkezden çeşitli illere gönderilmesinin yerinde olacağı görüşünü ikinci raporunda da yinelemiştir (BCA, 180.9.0.0/242.1212.29).

Raporun son kısmında ise "Film Teşkilatına Dair" isimli bir bölüme yer verilmiş olup, Türkiye'deki film konusuna ilişkin idari yapılanmadan bahsedilmiştir. Şakir Bey, sinemanın önemini "Film elifba derecesinde mühim bir talim ve terbiye vasıtasıdır. Yüzde altmıştan fazlası okuma yazma bilmeyen memleketimizde filmlerden istifade gayet sarih bir suret teşkil eder "sözleriyle açıklamıştır. Maarif Vekâletinde okullar dışında henüz "Talim ve Terbiye Müdüriyeti" unvanıyla bir daire bulunmadığı için vekâlet bünyesinde yer alan Hars (Kültür) Dairesi'nin halkın terbiye işlerinden ${ }^{d}$ sorumlu olarak bu konuya eğilmesinin öneminden bahsetmiştir. Bu noktada Hars Dairesi içerisinde bir "Terbiyevi Film Kütüphanesinin" kurulmasının düşünüldüğünü ve burada bulundurulacak filmlerin bir kısmının doğrudan doğruya Türk kültürünü ilgilendiren Türk sanat ve etnografyası, Türk coğrafyasına ilişkin filmler olup geri kalan kısmının ise Avrupalı şirketlerden alınan eğitici filmler olacağı belirtilmiştir. Buradaki filmlerin Anadolu'nun muhtelif yerlerindeki okullara ve Türk Ocağı gibi halka açık mekânlara gönderilebileceğinden bahsedilmiş, ayrıca bu filmlerin ilgili dairenin seyyar sinema makineleri vasıtasıyla çeşitli kasaba ve nahiyelerde gösterilmesine de imkân sunacağı belirtilmiştir (BCA, 180.9.0.0/242.1212.29).

Şakir Bey, filmlerin halkın eğitiminde oldukça önemli bir rol oynadığını ve bu işe ciddiyetle yaklaşıldığında birkaç sene içerisinde halkın, sinema sayesinde dünya genelindeki modern yaşam tarzlarını görmesiyle birlikte toplumsal bir devrimin yaşanacağını belirtmiştir. Milli sanatın bir şubesi olan milli filmlerin himaye edilmesinin Hars Dairesinin bir vazifesi olduğunu, Türk ruhunun ve Türk zevkinin tercih edeceği, Türklüğün önemli meselelerini konu edinen milli filmlerin çekilerek dünyaya gösterilmesi gerektiğinin de altı çizilmiştir. Çekilecek Türk filmlerinin, İtalyanların tarihi, Danimarkalıların toplumsal, Amerikalıların doğa filmleri ile kıyaslandığında bir çığır açarak diğer ülkelere rakip olabileceği belirtilmiştir. Bu şekilde raporunu tamamlayan Şakir Bey, raporuna şu sözlerle son vermiştir: "Âlem Türklerden de alelade bir taklit değil, belki medeniyet-i umumiye hesabına asli bir kıymet koymamızı bekliyor. Milli Türk filmleri çoğalırsa Amerikan, Alman, Fransızların Şarkiyata dair hazırladıkları sahte ve yalancı filmlerden ecnebi gaip edecektir." (BCA, 180.9.0.0/242.1212.29). Şakir Bey, Batı dünyasında çekilen filmlerde işlenen Türkiye olgusunun yanıltııı propagandalara gerçeklerden uzak bir şekilde işlendiğini, bu durumun ortadan kaldırılması için yerli Türk sinemasının gelişerek kendisini ifade eden güçlü yapımlar ortaya koyması gerektiğini ifade ederek sözlerini tamamlamıştır.

\section{Sonuç}

Sinemanın zamanla yaygınlaşarak popüler bir eğlence aracı olmasının yanı sıra geniş kitlelere ulaşabilmeyi sağlayan önemli bir iletişim ve propaganda aracı olması, Türkiye'deki siyasi otoriteler tarafından kavranmış ve sinemanın milli menfaatler doğrultusunda kullanılmasını gündeme getirmiştir. Osmanlı'nın son dönemlerinde gündeme gelen sinemanın eğitimde bir araç olarak kullanılması fikri, yeni kurulmuş olan Türkiye Cumhuriyeti döneminde de gündeme getirilerek bu konuda somut adımların atılması istenmiştir. Böylelikle halkın ve öğrencilerin eğitiminde modern araçların kullanılması yoluna gidilmiştir. Konuya ilişkin politikaların merkezi olan Maarif Vekâleti, diğer ülkelerde örnekleri görülen sinemanın toplumun ve özellikle öğrencilerin eğitiminde modern bir öğrenim aracı olarak kullanılmasının yerinde olacağı kanaatine varmış ve bu amaçla sinema konusunda uzman olarak görülen Şakir Seden'den konuya ilişkin bir rapor hazırlamasını istemiştir. Türkiye'de sinemanın eğitimde bir araç olarak kullanılması fikri, Türk toplumunun ihtiyacı olan bilgi, mesleki tecrübe ve genel kültür bilgisinin arttırılması amacını taşımışır.

Şakir Beyin hazırladığı rapor, genel olarak öğrencilerin ve halkın eğitimi için sinemanın etkili bir araç olarak nasıl kullanılabileceğini anlatmaktadır. Seden Raporu iki farklı rapordan oluşup ilk raporda 10.000 liralık bir bütçe ile yapılabilecek faaliyetler sıralanmıştır. Ancak Maarif Vekâlet'inin bu işlere ayrılacak bütçeyi 5000 lira ile sınırlaması üzerine yeni bir rapor hazırlanmıştır. Seden, raporunda Türkiye'de sinema sektörünü denetleyen merkezi bir idari

\footnotetext{
d Terbiye kelimesi, burada eğitim anlamında kullanılmış olup o dönemde eğitici-öğretici ve bilimsel filmlere "terbiyevi filmler" adı verilmekteydi (Arasan, i. (2020).Terbiye Treni (Seyyar Terbiye Sergisi). Atatürk Ansiklopedisi. https://ataturkansiklopedisi.gov.tr/index.php?title=Terbiye_Treni_(Seyyar_Terbiye_Sergisi)\&action=edit (Erişim Tarihi: 28.02.2021).
} 
yapının tam anlamıyla henüz oluşturulamadığını, cumhuriyetin ilk yıllarında milli sinemanın yeterli düzeyde gelişmediğini, sinemacıların eğitici filmler yerine daha çok rağbet gören macera, aşk ve komedi filmlerini tercih ettiğini belirtmektedir. Buna göre Türkiye'de sinema gösterimi yapan girişimcilerin olaya bir kültür sanat faaliyetinden çok ekonomik bir faaliyet olarak baktığı anlaşımaktadır. Şakir Bey, raporunda genel olarak halkın ve öğrencilerin eğitiminde terbiyevi filmler olarak zikredilen eğitici-öğretici bilimsel filmlerin izletilmesinden ve halkta milli bilinci uyandıracak, yaşadığı coğrafya ve tarihi geçmişi kavramasına yardımcı olabilecek belgesel filmlerin çekilmesinden bahsetmiştir. Böylelikle okullarda ve halka açık yerlerde izletilen filmler aracılığıyla sinemanın Türk modernleşmesine katkı sunan bir araç olması hedeflenmiştir Sinema yapımlarının kalitesine de değinilen raporda, Türk sinemasının taklitçi zihniyetten uzak, dünya sinemaları arasında hatıı sayıır yapımlarla öne çıkarılması gerektiğinin altı çizilmektedir. Bununla birlikte Batı dünyasının sinemalarda anlattığı Doğu kavramının yanlış ve çarpık bilgilerle tasvir edildiği, bu durumu tersine çevirecek yerli yapımların olmadığı vurgusu da yapılmaktadır. Doğu dünyasına ilişkin olumsuz aktarımlar içeren Batı yapımı filmlere cevap verebilecek nitelikte filmlerin çekilmesiyle bu yanlış durumun bertaraf edilmesi gerektiği raporda belirtilen bir husus olarak ortaya çıkmaktadır. Rapordan çıkarılan bir diğer sonuç ise İstanbul'daki yerli ve yabancı okulların taşradaki okullara nazaran daha iyi imkânlara sahip olmasıdır.

Şakir Seden'in raporunun merkezine koyduğu ve Kazım Karabekir tarafından da dile getirilen Film Kütüphanesi projesinin mali sıkıntılardan dolayı gerçekleştirilemediği görülmektedir. Bu durumun sebebi, savaş yıllarının getirdiği mali kısıtlıık olmakla birlikte yetersiz olan bütçenin öncelikli görülen alanlara ayrılmasından kaynaklanmaktadır. Raporda elde edilen bir diğer sonuç ise modern tekniklerden istifade etmeye çalışan Maarif Vekâletinin, asında kendi idari teşkilatını da modernleştirmesi gerektiğidir. Şakir Seden, mevcut Maarif teşkilatının ihtiyaca cevap verebilmesi için bazı yeni idari birimlerin oluşturulması gerektiğini ifade etmektedir. Bu bakımdan, Türkiye Cumhuriyeti, her ne kadar yeni bir devlet olarak ortaya çıkmış olsa da, kurumsal anlamda devlet teşkilatı olarak Osmanlı Dönemi'nin bir devamı niteliğinde olup, devlet işleyişinde eski düzenin devam ettirildiği anlaşılmaktadır. Bu bakımdan devlet teşkilatının da modernleştirilmesi gerektiği de çıkan sonuçlar arasındadır.

Seden Raporu bir bütün olarak ele alındığında dönemin eğitim politikaları, Türk sinemasının durumu, sinemalarda gösterilen filmlerin konusu ve menşeleri, sinema filmlerinin fiyatları, Türkiye' deki sinema salonları ve sinema salonlarına sahip okullar hakkında bilgiler içermektedir. Bu yönüyle Türk sinema tarihi, Cumhuriyet Dönemi kültür sanat faaliyetleri ve milli eğitim politikaları konusunda çalışan araştırmacılara önemli bilgiler sunmaktadır.

\section{Kaynakça}

Cumhurbaşkanlığı Devlet Arşivleri Başkanlığı Osmanlı Arşivi (BOA)

Bab-ı Ali Evrak Odası 829/62116: Hicri 10.03.1314.

Yıldız Perakende Elçilik, Şehbenderlik ve Ateşemiliterlik, 40/1: Hicri 03.01.1320.

Yıldız Perakende Arzuhal, Jurnal, 46/16: Hicri 10.12.1320.

Dâhiliye Kalem-i Mahsus, 63/49: Hicri 14.01.1332.

Maarif Nezareti Tedrisat-ı Ibtidaiyye, 514/14: Hicri 12.10.1332.

Maarif Nezareti Mektubi Kalemi, 1229/120: Hicri 05.12.1335.

Maarif Nezareti Mektubi Kalemi, 1230/37: Hicri 16.12.1335.

İrade Dosya Usulü, 166/19: Hicri 28.02.1338.

Cumhurbaşkanlığı Devlet Arşivleri Başkanlığı Cumhuriyet Arşivi (BCA)

30.10.0.0/146.43.5.

30.10.0.0/146.43.3.

180.9.0.0/242.1212.29.

30.10.0.0/86.566.9

TBMM Tutanak Dergisi, D.1, C. 6, B. 101, O. 2: Rumi (R) 22.11.1336. 
TBMM Tutanak Dergisi, D. 4, B. 64, O. 1, R. 25.2.1341

Arasan, i. (2020).Terbiye Treni (Seyyar Terbiye Sergisi). Atatürk Ansiklopedisi. https://ataturkansiklopedisi.gov.tr/index.php?title=Terbiye_Treni_(Seyyar_Terbiye_Sergisi)\&action=edit (Erişim Tarihi: 28.02.2021).

Arpad, B. (1968). Ekonomi Temeli Açısından Türk Filmi. Türk Dili Sinema Özel Sayısı, (196), 288-291.

Başbakanlık Devlet Arşivleri Genel Müdürlüğü. (2015). Arşiv Belgelerine Göre Osmanlı'da Gösteri Sanatları (Haz. Resul Köse \& Muzaffer Albayrak), Bion Matbaacılık, İstanbul.

Bazin, A. (2011). Sinema Nedir (çev. İbrahim Şener), Doruk Yayınları, İstanbul.

Betton, Gerard. (1995). Sinema Tarihi: Başlangıcından 1986’ya Kadar (çev. Şirin Tekeli), İletişim Yayınları, İstanbul.

Filmer, C. (1984). Hatıralar. Emek Matbaacılık, İstanbul.

Gökmen, M. (1989). Başlangıçtan 1950’ye kadar Türk Sinema Tarihi ve İstanbul Sinemaları. Denetim Ajans Basımevi, İstanbul.

Odabaş, B. (2012). Türk Sinemasının Kuruluşunda Ordunun Rolü, Belge(Sel) Film Ve Kurtuluş Savaşı Filmleri. İstanbul Üniversitesi İletişim Fakültesi Dergisi, (24) , 205-212.

Özgüç, A. (1990). Başlangıcından Bugüne Türk Sinemasında İlkler. Yılmaz Yayınları, İstanbul.

Özön, N. (1968a). Türk Sineması Kronolojisi (1895-1966). Bilgi Yayınevi, Ankara.

Özön, N. (1968b). Türk Sinemasına Toplu Bir Bakış. Türk Dili Sinema Özel Sayısı, (196), 266-287.

Özuyar, A. (2008). Sinemanın Osmanlıca Serüveni. De ki Basım Yayın, Ankara.

Özuyar, A. (2019). "Tarih Muallimi ve Sinema Mütehassısı Şakir Bey’in Birinci ve Ikinci Raporlarının Sureti 1925”. Türk Sineması Hakkında Raporlar (edt. Ali Karadoğan), De ki Basım Yayın, Ankara.

Pudovkin, V. I. (1966). Sinemanın Temel İlkeleri (çev. Nijat Özün), Bilgi Yayınevi, Ankara.

Ryan, M. ve Lenos, M. (2012). Film Çözümlemesine Giriş. De ki Basım Yayın, İstanbul.

Sadakaoğlu, M. (2020). Erken Dönem Sovyet Propagandası: Sinema, Seramik ve Afiş. Karadeniz Uluslararası Bilimsel Dergi, 1(45), 112-128.

Sevim, S. (2016). Muhsin Ertuğrul: Türk Sinemasının Kurucusu mu Yoksa Günah Keçisi mi?. İnsan ve İnsan, 3(10), 64-83.

Soysüren, A. ve Yıldız, N. (2017). Erken Cumhuriyet Dönemi'nde Türk Sinemasının Ulus-Devlet Politikalarıyla İlişkisi Üzerine Bir Değerlendirme. Karadeniz Uluslararası Bilimsel Dergi, 35 (35) , 95-110.

Şahin, M. (1998) Türk Eğitim Sisteminde Yabancı Eğitim Uzmanlarından Yararlanma. Toplumsal Tarih, 9(54), 12-18.

Yurdigül, Y. ve Elitaş, T. (2013). Türk Sinemasında Şive Ya da Ağız Kullanımının Karakter Yapılandırmasına Etkisi. Atatürk İletişim Dergisi, (5) , 43-62. 